\title{
Scavenging for Survival and its Health Implications. The Nexus between Unemployment and Ill-health
}

\author{
CHUX GERVASE IWU, FRANKLIN IKENNA EZE \\ Faculty of Business and Management Sciences \\ Cape Peninsula University of Technology, South Africa
}

\author{
ABDULLAH PROMISE OPUTE \\ GProm Solutions, Salzkotten, Germany \\ GIANNI UTOMHE DONGO \\ Nigeria Governors’ Forum, Abuja, Nigeria
}

\author{
OLUWATOSIN WURAOLA DONGO \\ Infectious Diseases Institute, College of Medicine, University of Ibadan, Nigeria
}

\begin{abstract}
According to a popular adage, when the going gets tough, the tough gets going. With unemployment on the constant increase in South Africa, people are becoming more relentless in seeking means to earn a living. Waste picking has become, for example, an option for individuals in responding to the economic challenge in order to provide for themselves and families. By odd, the researchers refer to foraging in bins for items that have been discarded by others, which may be sold for cash. Although this practice offers an opportunity for self-employment, there is also a concern that those who deal in waste may be exposing themselves and perhaps their families to social stigma and health problems. This article looks at both the challenges of waste picking (more specifically health) and the desperate state of unemployment in South Africa. In doing that, we aim to address three central questions: (1) why are people waste picking? (2) Is waste picking a sustainable venture? and (3) what are the challenges in waste picking? To obtain deeper insights into the themes captured in the aforementioned research questions; face to face interviews were conducted with participants. Empirically, four central factors push participants into waste picking ventures: unemployment, retrenchment, unemployability, and the need for augmented income. Also, we found that although waste pickers continue the practice to sustain themselves and their families, waste picking does not sufficiently offer sustainable income, improved livelihoods nor reduced dependency on public social and health systems. There is a need to enhance the capacity of the South African public health system to adequately cater for those who regularly need its services and as this study has shown, the continuous practice of waste picking is synonymous with ill health and pressure on public health systems. We flag directions for future research.
\end{abstract}

Key-Words: - Bin Scavenging; Health Risks; Survival Ventures; Push Factors; Sustainable Income; Waste Management; South Africa

Received: September 15, 2020. Revised: December 17, 2020. Accepted: December 28, 2020. Published: January 12, 2021.

\section{Introduction}

A common adage states that when the going gets tough, the tough gets going. By implication therefore, perseverance is a rational human response when faced with very challenging circumstances. Globally, the economic landscape is becoming more challenging, and as economies fail in their attempt to effectively respond to this growing challenge, individuals are taking up the challenge by resorting to their own ways of responding to this challenge to provide for themselves. It is against this background that this study illuminates South Africa. Given the high unemployment rate in South Africa [1], it is not surprising that there are people who would rather opt for odd means of providing for themselves and families. By odd, the researchers refer to foraging in bins for items that have been discarded by others, which may be sold for cash. Although this practice 
offers an opportunity for self-employment, there is also a concern that those who deal in waste may be exposing themselves and perhaps their families to social stigma and health problems. This study seeks to illuminate the challenges of waste picking (more specifically health) and the desperate state of unemployment in South Africa. Within that focus, we aim specifically to explore three key questions:

(1) Why are people waste picking?

(2) Is waste picking a sustainable venture?

(3) What are the challenges in waste picking?

Waste picking refers to collecting domestic or industrial waste for the purpose of selling them. Some writes have indicated that waste picking has socioeconomic value to a society. These include that of helping to keep a city clean e.g [2] and reducing the number of unemployed through selfemployment [3], [4]. Waste picking is considered a more decent term for a practice that some would rather refer to as scavenging, which is apt for the practice of inspecting or going through waste from garbage bins for purposes of selecting items with perceived economic value [5].

Increasing poverty and unemployment have forced many individuals into seeking income opportunities in the informal economy e.g. [6], [7]. According to Statistics South Africa (2019), South Africa has a high rate of unemployment as $27.6 \%$ of its citizens are currently unemployed as of the first quarter of 2019. To survive therefore, some of the unemployed are resorting to waste picking to feed themselves and their families [8]. Indeed, as Njoroge et al. (2013) [9] note, the population of waste pickers is increasing proportionately with the rise in unemployment. The number of waste pickers in South Africa almost doubled from 37,000 in 2004/5 to approximately 51,500 in 2016 [10].

In South Africa, as cited by Benson and VanqaMgijima, [11], waste picking is a common activity carried out by the poor as a desperate measure to feed their families. [12] reinforces that view and notes that people who are mostly involved in waste picking are the poor in society, low skilled workers, who in the absence of formal jobs settle for selling goods and services in the informal sectors. On their part, [13] add that that people who engage in waste picking are mostly individuals with low employability due to lack of necessary skills required to acquire a job in the labour market. They settle for these low types of jobs that do not require any special skill.

Domain literature has documented that waste pickers encounter several challenges in their day to day activities. For example, [14] noted that the major challenge faced by waste pickers is that they are not recognized. According to them, if waste pickers were accorded recognition, that would go a long way to enhance their performance. Insight from South Africa suggests that unemployment and poverty, which are the major reasons for engagement in waste picking, are associated with mental illness [15]. Similarly, research piloted in Mumbai which examined the psychological state of waste pickers found that waste pickers have an unhealthy psychological state [7].

Similar to South Africa, waste picking has been documented as a source of income and livelihood in several developing countries such as Brazil and India [16],[7],[17]. In these countries, waste picking is seen as an alternative to self-employment. In the case of South Africa, [18] do not only reinforce the prominence of waste picking ventures in the South African informal economy but also flag them as providers of solutions to society. It is therefore necessary to properly understand the role of informal waste pickers in the broader waste management system. Comprehensive research is therefore required towards informing policy. This paper therefore highlights the importance of waste picking in terms of economic survival of those who engage in it but at the same time adds to the literature on health implications of the practice. Public health sector in South Africa is under pressure by those who use it. Waste pickers are said to be poor and often sick. This paper brings to the fore the necessity for attending to public health services so as to make it possible for waste pickers to access public health services. In that regard too, this paper takes a holistic approach to highlight hands-on-deck initiatives that the South African policy makers can embrace in achieving effective waste management and driving economic growth as well as securing well-being of scavengers.

The rest of the paper is structured as follows: First, literature is reviewed on unemployment and waste picking associated health issues. Thereafter, the methodology is described, which is then followed by the results and discussion. We conclude the paper by explaining the implications of our study while at the same time proffering some future research directions.

\section{Effect of Unemployment in the Society}

Unemployment has been a topic of core concern to scholars for the plausible reason that it has a 
major impact on the economy e.g. [19], [20] and the well-being of individuals e.g. [20], [21], [22], [23]. The economic costs of unemployment stem from inefficient use of resources, less tax revenue, loss of human capital, amongst others e.g. [24], [25], [26], while individual well-being implications (elaborated next) can manifest in several ways e.g. [27], [21], [22].

In line with the conceptual framing of this study, the individual well-being implication perspective of unemployment is the focus of this study. This social consequence of unemployment perspective which is underpinned by sociological and psychological foundations captures multiple features in the understanding of unemployment and individual well-being. Commenting on the social consequences of unemployment, [28] state: You don't live when you are unemployed - you exist [27], (p.1). Critically analysed, that statement suggests unemployment would have vast implications for the well-being of the individual. In their study for the Business Council of Australia, [27] summarised the social consequences of unemployment thus:

"The personal and social costs of unemployment include severe financial hardship and poverty, debt, homelessness and housing stress, family tensions and breakdown, boredom, alienation, shame and stigma, increased social isolation, crime, erosion of confidence and self-esteem, the atrophying of work skills and ill-health.” (p.1).

Scholars have categorised the social consequences of unemployment to include physical, mental and emotional elements e.g. [29], [30]. It is obvious from the above comment [27] that the first major consequence of unemployment for the individual is financial hardship and a tendency to be driven into poverty e.g. [31], [20]. When individuals become unemployed, their spending power and that of their family members would diminish drastically e.g. [32], [23]. Furthermore, their ability to save and contribute to the economic sustainability wheel is adversely affected, as they instead rely on their initial savings to make ends meet.

Unemployment does not only increase the risk of poverty [20], [32] but also drives societal inequality, outcomes that further cause series of social effects on the unemployed individuals directly, their families and their immediate communities [20], [22]. A critical reason for this range of implications is that income is a significant individual well-being factor [23].

Unemployment is a serious matter and has vast devastating consequences on economic welfare, and exerts a push influence on crime, misery and social instability on those affected e.g. [33], [32]. Extending the social instability notion, scholars also argue that unemployment contributes to deprivation and exclusion in communities e.g. [34], [20]. In further literature, it has been evidenced that prolonged joblessness can affect the mind and physical health, which can be linked to stress and depression [35]. That insight enhances prior literature by [36] who suggested that unemployed people experienced unhappiness, anxiety, loss of self-esteem leading to depression, and increase in suicide rates. Furthermore, Bell and Blanchflower [36] point out that the longer one stays unemployed, the lesser the likelihood of finding employment thus giving rise to crime rates. From the point of crime rate, that insight reinforces [37] study which somewhat linked high unemployment to high crime rate.

Furthermore, xenophobic attacks were also linked to unemployment as local South Africans blame foreigners for their joblessness [38]. Given these stark socio-economic conditions, it is no surprise that South Africa has high crime rates. Crime has been characterised as one of the most difficult challenges in post-apartheid South Africa [39].

Substantial literature documents the connection between unemployment and crime [40], [32], among others. For example, further insight on South Africa [41] found a relationship between crime and youth unemployment, insight that lends support to earlier literature [42] which noted that when youths are employed, the number of violent, criminal activities, drug addiction as well as prostitution in a country reduce significantly.

\section{Solution to Unemployment}

Unemployment is an increasing contemporary global challenge. Expectedly therefore, combating this challenge is a central theme for academics and policy makers e.g. [43], [44], [45], [46]. From these streams of literature (see also [47]), critical mechanisms for combating unemployment include, amongst others, supporting the economic sector in the job creation drive, offering the unemployment support and training to enhance their fit for existing jobs, promoting policies that motivate enterprises towards job creation, motivating enterprise drive through tax reliefs, and ensuring management mechanisms for monitoring and controlling the labour market.

Based on a combination of studies, [46] highlights the employment policy implementation trends in Germany and the UK from the point of the 
mechanisms for coordination, accountability and support. That report documents that in the time frame 2003 to 2016 Germany employment policies involved labour market reforms designed strategically to minimise unemployment and securing good life for individuals - these involved employment promotion initiatives, labour market instruments, youth guarantee, Hartz IV initiative (merging unemployment assistance and social assistance), amongst others (for more details, see [48]). On their part, the UK has focused on enhancing the welfare package and utilised three major employment policy mechanisms in the time frame 1997 to 2010: (1) training, job search assistance, and work experience placement; (2) income benefits, subsidies and incentives; and (3) social services and other policies (e.g. family and health).

Focusing mainly on youth unemployment, [44] highlight education and training as core intervention mechanisms for combating unemployment. Elaborating, they note that the intervention initiatives would include vocational education, apprenticeship and training programs as well as fostering entrepreneurship. [43] which focused on individuals with long-term unemployment history offers insights that lend support to a number of the intervention approaches mentioned earlier. That study argues that one useful way of combating unemployment is by offering incentives to private sector employers to motivate them to recruit applicants with gaps in their employment history. For example, the government can offer various tax credits (e.g. work opportunity tax credit) to such employers. Furthermore, federal and state governments can offer cash grants and tax credits to unemployed individuals to enable them participate in training and apprenticeship programs towards updating their knowledge and skills to meet current market needs.

Further literature also flags foreign investment as an intervention option for combating unemployment. For example, [49] found that foreign investments had a high impact on employment creation in Tanzania. Aligning to that logic, we forward that the South African government should create an enabling environment free of crime to attract direct foreign investment which would help to reduce the unemployment crises currently experienced in the country.

Foreign direct investment is the flow of capital from the investor's country to an enterprise operating outside of the investor's country [50]. Foreign direct investment has been positively and meaningfully contributing to economic growth and development through job opportunities and technological transfer in many developing nations of the world. That substance has been reinforced by [51] who noted that foreign direct investments have a positive effect on employment and economic growth in most developing nations.

Scrutinizing the elements that influence foreign direct investments coming into African countries, Kariuki [52] examined the data from 35 African countries, and suggests that the inflows of foreign direct investment are important for African nations as they promote economic growth and development. Keying into that logic, we contend that foreign direct investments in key areas where there is lack of technical skills in Africa, for example waste management, will go a long way in combating unemployment in the African setting. We also forward that improved infrastructural development and increase in trade openness would have a significant positive effect on the foreign investment directed towards a country.

According to the report presented by South Africa's [53], increased foreign direct investments were recorded from January 2003 to July 2015 into the South African economy. These contributed to the South African economy recording a total capital investment of US\$71.2 billion over this period. A total of 189,724 jobs were created by the inflow of these foreign investments into the South African economy. With this in mind, the South African government should do everything necessary to entice foreign investors to invest in South Africa which will in turn create employment in the country.

\section{Surviving Unemployment}

Given intensifying unemployment, millions of people around the world are seeking ways to make a living by collecting, sorting and selling materials that someone else has thrown away e.g. [54], [7], [16], [55]. According to StatsSA (2017), more than $51 \%$ of South Africans live in poverty. Little wonder therefore that a lot of South Africans are resorting to picking waste and selling to manufacturing companies in order to support their families. [3] notes that these waste pickers are forced to create their own jobs in the informal sector as means of survival. According to WIEGO (2011) waste pickers are a susceptible group in terms of poverty and are often viewed as the poorest groups in a country.

According to Viljoen et al. (2012), a plausible reason why the unemployed easily endorses waste picking as a way of surviving unemployment is that there are no barriers, skills or requirement to 
entering waste picking. As they elaborated, the unemployed can simply join to make ends meet or to add to their income. Essentially, since there is no barrier to entry in this 'business', the little money made from collecting and disposing of waster serves the unemployed immediate needs. In South Africa, more than $1.5 \%$ of families generated an income through gathering and selling recyclable waste in 2009 with Gauteng alone having an estimated 3100 families deriving an income from these activities in 2009 [57]. In that period, around 6000 individuals in the city of Tshwane depended on some form of waste picking for their survival [58].

Further literature on the South African setting e.g. [11] documents that in Cape Town the majority of waste pickers moved into this occupation after having lost their jobs due to retrenchments. The high levels and growing struggle in finding work render waste picking "an easy way out". Similar trend is also documented in Johannesburg [59] and Free State [60]. In their study, [60] noted that 49 percent of the respondents said they had "no other option" available other than waste picking.

Though largely informal entrepreneurial activities, waste picking also plays an important role in the economy chain. According to Gunsilius (2012), waste pickers perform a valuable role in society and support environmental sustainability. In cities with no household collection or municipal recycling systems, waste pickers are important actors in addressing a key 21st-century challenge the increasing quantity of solid waste [62]. Waste pickers protect the environment by enabling materials to be reused or reprocessed, and by identifying valuable materials for global recycling industries [62]. Finally, waste pickers generate employment for themselves and others, creating opportunities where they might not exist otherwise.

\section{Management of Waste and Health Risks Associated with Bin Scavenging}

Waste is defined as materials that are not prime products (products produced for the market) for which the generator has no further use in terms of his/her own purposes of production, transformation or consumption, and of which he/she wants to dispose [63]. Waste could take different forms: municipal waste (household solid waste/trash, commercial wastes), sewage, industrial waste, biomedical waste (waste from hospitals, laboratories, etc.). Historically, waste has always been treated with disdain and those associated with its removal viewed as cast-offs from society. For instance, slaves and criminals were mandated to clean sewers and streets in the old Roman civilization [64].

Given increasing urbanization and effects of climate change, effective waste management has become a global priority towards securing the health of individuals and healthy environment. Poor handling of waste, illegal dumping of toxic waste, waste accumulation resulting from delayed waste collection have been identified as responsible for increased incidences of cancers, respiratory system disorders, birth defects in the Campania region of Southern Italy [65]. Further literature has also attributed outbreaks of plagues such as the Bubonic plague in historic times to poor waste management the most recent being in India in 1994 e.g. [17].

Recycling of waste is recognized as one of the most important ways to prevent the catastrophe of global warming. It results in less waste being used for landfills thereby reducing release of toxic gases like methane associated with landfill sites (The Grand Traverse County, n.d.). It is for this reason that bin scavengers must no longer be viewed as society's cast-offs but people who provide an essential service for the environment. Their health and quality of life must be of paramount importance for the government. Hence one of the central objectives of this study is to look at health risks associated with waste scavenging towards underlining the common risks, as well as suggest mechanisms for mitigating the risks.

It is estimated that at least $2 \%$ of the world's population are presently engaged in scavenging [66]. For many of them, scavenging becomes the last resort towards alleviating poverty and earning some income to keep life going [5], [67]. According to insights from Thailand, a significant number embrace scavenging because it is a family business and or tradition [67]. Recent studies however suggest potential economic gain in the practice. For example, in their study of Pretoria, South Africa, [5] found the mean level of income among scavengers to be between $\$ 70-\$ 105$ per month which was slightly above the poverty datum level of $\$ 1.90$ daily [5], [68]. The same study established that there was a relationship between the number of hours spent scavenging and the resultant income, a finding that lends support to prior research that examined the Lagos, Nigeria [67] and Thailand [69] settings. [67] also identified other aspects of the economic value to include the sheer number of people involved and also the opportunity cost gained of having some of these individuals engaged in defined labour compared to social vices. 
Scholars have also stressed the pertinence of more effective ways of managing wastes to ensure that waste scavengers do not expose themselves to major health risks e.g. [70], [55]. While [55] found common mental disorders amongst waste pickers in their study in the Johannesburg, South Africa setting, [70] reported that waste pickers on landfills in four of nine of South Africa's provinces suffered from several health risks. Beyond the South African setting, this health risks contention has been supported. For example, in a study of four districts in Pakistan, [71] suggest a direct association of the quality of livelihood to the exposure to health risks and resultant health conditions. To elaborate, Jan and his colleagues found significant correlation between exposure to health risks and quality of life reported by scavenger children in the districts. Quality of life index was graded as good, fair and deprived and was based on six attitudinal proclamations. There was significant correlation between quality of life and picking of sharp objects or picking in an environment surrounded by flies and mosquitoes.

Further studies have categorised the health risks and hazards associated with scavenging to include; low back pain, common colds, skin rashes, conjunctivitis, diarrhoea, impetigo, headaches, nausea and vomiting e.g. [66], [5], [67], [69]. [5] identified the ranking order of prevalence of health issues amongst a small sample size of scavengers in Pretoria to be; cold and flu (81\%), feeling tired and weak $(71 \%)$, back pain $(65 \%)$, headache $(58 \%)$, shortness of breath (42\%), skin rash (45\%), diarrhoea (38\%), vomiting (34\%), conjunctivitis (24\%). On their part, [66] note that health issues related to the respiratory tract are attributed to toxic gases like methane and dioxin release at dump sites. In an area that has been called the triangle of death in Italy, some authors have attributed chronic or long-term exposure to waste, especially toxic waste, to be a risk factor for cancer. For example, scholars have argued that the high cancer mortality in the Campania region of Italy is due to illegal toxic waste dumping in the region e.g. [65], [72]. In a systematic review published in the International Journal of Environmental Research and Public Health, [73] emphasised the pertinence for further studies towards a better understanding of the aforementioned relationship since available data offer inconclusive cues because of failure to track exposure and difficulty in confounder control. Major confounders would include things like alcohol and tobacco use, socioeconomic status, genetic predispositions to include a few [74], [75]. As part of initiatives towards better understanding of the phenomenon, the Italian government in 2014 instituted the Land of Fires Decree that appropriated 25 billion $€$ of funds yearly (for 2014 and 2015) for "health screening" of residents in Campania and Apulia region, that were recognized by the WHO as high environmental risk areas since 1986 because of their metallurgic industries [65], [73]. Transporting the importance of understanding that relationship to the setting of this study, we emphasise the need for future research to evaluate any long-term waste health relationships in the African environment.

In conclusion, there is significant evidence that if these risks are mitigated, a greater number of scavengers would benefit from improved health and resultant quality of life e.g. [70], [55]. This study therefore aims to contribute to the scarce literature concerning health risks of bin scavenging in Africa, as well as add support to the advocacy for governments in Africa to take a more active approach in regulating this sector by legalizing and providing preventive health services to this crucial group of people.

\section{Research Methodology}

To fully understand the narratives of the bin scavengers, this study followed a qualitative approach. Specifically, semi-structured interviews were conducted with participants as that approach is suitable for obtaining detailed responses from respondents about complex issues [76]. Interviews were focused at understanding: (1) why the participants foraged bins; (2) whether bin foraging was a sustainable venture; (3) what dangers are there in foraging bins.

To achieve the objectives of the study, we followed methodological guideline for social science and medical research and ensured that the interview questions were in the form of themes e.g. [77], [78]. According to these scholars, themed question format facilitates intimate conversations between a researcher and a sample. Although questions that are posed seem usually broad, they provide scope for follow up questions [79]. Using themed questions guarantees consistency i.e. same questions are asked of each participant [80], [81], even though explanations or clarity are sought as the conversations continue.

This study is located in the South Africa setting where the local authorities are responsible for cleaning streets and removing bins from neighbourhoods. In order to identify the periods for dirt collection it was necessary to request the roster from the city council. This enabled us to access different persons involved in this venture. Bin 
removal takes place weekly. Each neighbourhood gets their bins ready for the scheduled day of collection by the respective government trucks, and on such days, bin pickers are found in such neighbourhoods. Essentially trucks go to designated areas daily to collect and empty bins respectively. Thus, we first identified the neighbourhoods to include in the sample. Thereafter, we scouted for possible subjects. In a bid to familiarize ourselves with the areas and likely participants, we thought it wise to approach the participants directly, and this was done at the times the participants were picking the bins. Firstly, the researchers introduced themselves as well as explained the research mission. Initially, some of the participants did not show interest in participating in the research. A primary reason for this is that bin foraging is often subject to social stigma e.g. [55], [2], [6], [82] as a result, they did not feel comfortable sharing their experience. Secondly, as some of the participants reported, although they had been contacted in the past to participate in researches of this nature, there was no further follow-up, so they thought our effort (researchers') could be an attempt to waste their time. To motivate them to participate, we clearly explained the importance of this research and the potential in driving policy change that could enhance their future job prospects. Secondly, to motivate them, we offered them meals (in the form of sandwiches) and coffee during the interviews. When willingness to participate was confirmed, times and dates for interviews were agreed. A major challenge we often encountered was however that on a number of occasions some of them did not honour the agreed appointments, and in such cases we had to seek others who were willing to participate. This experience of ours is similar to what [83] reported regarding waster pickers that they are not quite trusting of researchers' intentions and as such may not present themselves for a study of this kind. WIEGO also reported that waste pickers "are mobile and their population may fluctuate by season”.

Interviews with participants were intended to include at least 45 persons. However, following the theoretical saturation logic [84], interviewing was terminated after participant 39 as no further new ideas were emerging from the interviews. Each participant was assured that his/her identity as well as data collected during the interviews would be held confidential. All the interviews were audiorecorded after obtaining the respondents' consent. Also, to ensure that we accurately captured the participants' views, memos were written during the interviews. The interviews, which lasted between 45minutes and 60minutes, were conducted over a period of 10 weeks.

\section{Analysis and Findings}

We derived our sample from the inestimable, but very large population of waste pickers in the neighbourhoods of Southern suburbs in the Cape Metropolitan Council. 39 participants comprising 31 males and eight females participated in this study. The demographics of the participants are presented in Figure 1 below. Eight of the men were between 15 to 25years old, while 15 of them were between 26-35years old. Six of the males were between 3645years; only one was within the range of 46 to 45years and 56years and above respectively. As stated earlier, only eight females participated in this study. Five of them were between 15 to 25years old, while the rest were between 26 and 40years old.

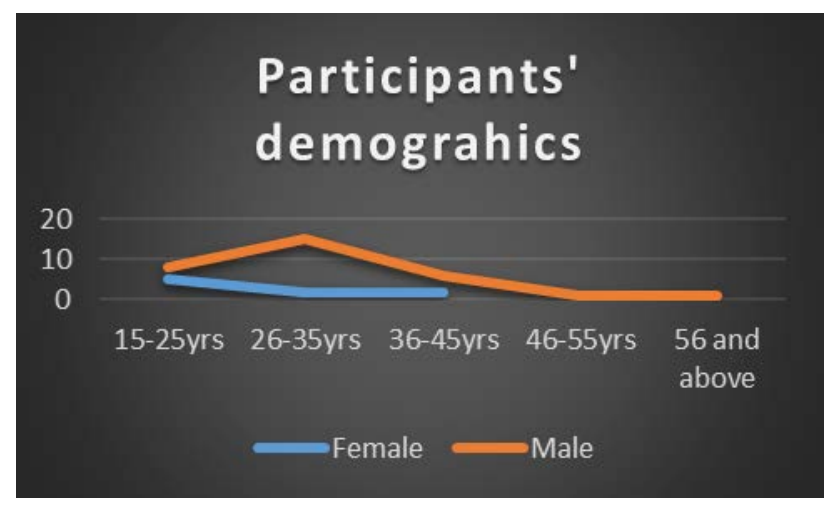

Fig. 1. Participants' demographics. Source: Authors' compilation

The youngest participant was a 15 -year-old male, while the oldest participant, a 63-year-old male had been scavenging bins long before South Africa's independence in 1994. While we wanted to know the extent to which the participants were educated, we realised that majority of them were not willing to offer that piece of information. What we however gathered was that only seven of them had completed secondary education. Four out of the seven were females (aged between 15 and 25 and 26 and 35year ranges), two males within the 26 to 25year range, and one male within 36-34year range.

To capture the meaning in the data for this study, thematic analysis of interviews was used [85], [86]. To achieve the thematic content analysis, we utilised interpretive analysis that involved an iterative approach and thorough reading of raw data to derive the themes for this study e.g. [85], [87]. This involved a back and forth reading of the transcribed interview texts to get a better understanding of the data. During that process, memos were written to 
document the core cues relating to the themes [88], [87]. Based on the analytical evidence, the central themes for organising the findings include:

(1) Entering the 'business' of bin foraging

(2) Sustainability of the 'business'

(3) Challenges

Table 1, in Appendix, shows a memo sample written during the interview process, while the results from this study are summarised in Figure 2.

\section{Entering the 'business' of bin foraging}

We started off by asking the participants to tell us what they mostly picked. Almost all the participants indicated the following (in no particular order): used clothing, electrical and electronic items or components, empty containers and bottles, metals and furniture. Interview results showed that participants focused on this range of items because could easily find buyers for such items. In explaining the range of products they picked, the participants shed light on what prompted them to go into bin scavenging:

"I am waste picking to be able to keep me and my family going. If I do not do this, I am unable to feed my children. I don't have a wife. The wife left me" (Interviewee 2)

"I have no other means of getting money. If I am not able to pick items that will give me money daily, I will not be able to feed. So, I make sure that I pick things that I can sell quickly" (Interviewee 7)

"Surviving in South Africa without a job is a serious problem, and when you don't have friends or relatives to help you, the problem becomes bigger. I became an orphan at a very young age, and I used to work at a warehouse but then I lost job, and without any training, it became very difficult for me to get a job. And one day, I met somebody who does waste picking and that is how I started waste picking too to make sure that I can feed myself without doing something silly" (Interviewee 34).

The comments above document insights into why the participants started foraging bins. Overall, the responses we received ranged from loss of job to having to feed children because of wife leaving, as core push factors for bin scavenging. Other responses underlined lack of parental support and lack of government support. For example, Interviewee 12 commented: "parents lost their job and so I thought of helping". Elaborating, this participant stated: "I had to do something in order to assist because there are brothers and sisters". Commenting, a middle-aged male participant (Interviewee 25) said: "When I finished school they did not provide any job. So a friend of mine who did this said I can work with him. I must say at least I am able to do something for myself now". When asked who he was referring to by the word "they", this participated responded thus: "the government is not doing enough to provide jobs for the people and this is frustrating." The insights suggest that the participants are somehow generating some income through bin scavenging to enable them keep life going somehow, evidence that reinforces that "waste picking provides crucial income for people and households" e.g. [82]. Furthermore, these insights lend support to the literature that underlines waste picking as a way to earn a living e.g. [11], [59], [60], [6].

Another insight derived in exploring the reasons why participants forage bins is that some of the participants saw bin scavenging as an opportunity to augment their incomes. Thus, some participants were foraging bins as a part-time job to augment their incomes. A female participant (Interviewee 30), in company of an older man said: "I do this when I can, ...., I have a job but you see the items sell and so I use the things I pick to make up the small wage I receive. " This is similar to what [4] and [3] reported regarding the necessity of waste picking in augmenting one's income.

\section{Is it sustainable to pick waste?}

To understand the extent to which waste picking is a sustainable venture, we asked participants: is the money you make enough for your needs? A significant majority of the participants said waste picking was not sufficiently supporting. To emphasise their notion that waste picking was not a sustainable venture, most participants commenced their response to that question with "not at all" or "certainly not" or "of course not". For example, Participant 17 commented thus: "of course not! I have many needs but I'm able to buy basics such as bread and sausages".

A central take from the comment of participant 17 (supported by a large majority of other participants), is that one cannot earn much from bin scavenging beyond meeting basic needs. Impliedly therefore, participants are only surviving on basic needs. These insights connect to the notion that poor people around the world live on basic necessities e.g. [2], hence participants would seek to provide basics such as bread and sausages for the people they support with their waste picking earnings. 
Some of the participants indicated that they engage in other 'businesses' so as to survive. Some of them stated that they are always on the lookout for extra work such as gardening, washing cars and several other chores including painting, etc. Two of the participants said they volunteer in their local church and in return they are handed food parcels. These responses further underline the fact what the participants earn from the scavenging jobs are not enough to enable them meet daily needs.

We also gathered from a few responses that participants could earn better than their daily returns, if they had skills and knowledge that could be utilised to enable then think of better ways of doing things. For example, participant 36, who commented, "I did not go to school and that's the reason I cannot get a job at a company", admitted that if he was educated, he would do many things differently and would earn more, but also added "you sure I will not do this job anyway."

Further interesting insight was also captured in the interview with participant 30 who scavenges bins part-time to augment her income. According to this participant, for individuals with moderate living standard, waste picking could provide a means of sustainable income, if one had necessary technical support: "Waste picking has been very helpful for me, ...... as a matter fact, it has been very rewarding. I know that if I decided to do this thing full time I could take a loan to buy myself machinery, I can make a good living from it, but I want to do it secretly because waste pickers are seen as trash in this society." These insights add support to [2] who noted that despite the shame and stigma that waste pickers may face, they may stay in the waste picking job as it enables them to meet their basic needs, and especially where there are no other alternatives for formal jobs.

\section{Challenges Faced by Bin Scavengers}

From the point of challenges faced by bin scavengers who participated in this study, three core factors were captured: (1) health issues; (2) lack of fund to enable them utilise more effective options; and (3) lack of government support and societal problems.

Primarily, we set out to understand the health challenges faced by participants through bins foraging. For the most part, the participants cried out for help regarding the health issues they confront. In fact, a male participant (Interviewee 27) said "If I can get a good job, I will be happy. This work is not very good. I get sick and I think it is because of this work". Another participant (Interviewee 4) added: "I have been to the doctor and they said I have certain germs. Sometimes, the government hospitals the queues are long. So I wait for long and I don't get the medicines. If you see my back and feet, and my stomach, you will see a lot of rashes. See my hands, it is full of rashes". In his response, participant 9 does not only highlight the nature of health issues he faces regularly but also supports the comment of participant 4 from the point of the government not providing adequate hospital facilities: "Since I started picking waste, I have been having constant headache, cough and skin rashes, because in searching for items for sale, I touch many dirty things and also breath in the dirty air in the bin areas. I don't have money to buy myself hand gloves or masks to protect myself when picking wastes. This health problem is a big problem for most of us in this job, because there are not enough hospitals to take care of us."

While highlighting the health hazards of waste picking, participants emphasised that they are aware that the health risks they face are huge and could have serious impact on their health and the health of their family members such as leading to early death, but they have no options than to continue bin scavenging, because if they do not do that, they and their families would die of hunger. For example, participant 20 said: "I have rashes on my fingers...my entire hand [motioning the hands towards us], but I don't care anymore. Sometimes I put some cream to rub over the rashes and move on. I have to make sure that I and my son have food to eat", while adding a religious tone, participant 3 said: "I know that in this job, I am surrounded by health dangers, but I trust my God who provides for the poor and the fatherless."

Thus, the common health problems among the participants from what we picked up included cough, respiratory problems and rashes, insights that connect to prior literature e.g. [66], [5], [67]. Also, two participants (37 and 8) mentioned constant backache as a health hazard of bin scavenging (elaborated next).

Another challenge faced by participating waste pickers relates to lack of finance to enable them explore ways of implementing their waste collection towards improving their earnings. Two participants (37 and 8) mentioned this as a significant challenge for them. Elaborating their experience and the challenge they face, the two participants who seem to focus on picking big and not-easy to transport items commented thus:

"I focus on picking things like furniture and computers because they give more money when you sell them. ..... But they are difficult to transport, I wish I could buy a bicycle, but I don't have the 
money, so I try to carry them on my shoulder and this causes big damage to my body." (Participant 37).

"I get back pains often, .... the reason is that many times I pick heavy furniture and carry them on my back as I don't have another way to carry them where I can sell them. There was a time I was thinking of asking for loan from the bank to buy a bicycle, but they will not listen to me because they look down on me as a bin scavenger, and even if they listened to me, I will not have the money they will require" (collateral, he meant) (Participant 8).

This evidence of health risks related to carrying heavy waste items on the back lends support to the evidence in [70] who described this nature of health challenges as ergonometric or musculoskeletal risks. Finally, respondents classified lack of government support and societal problems. On the one hand, some of the waste pickers gave the impression that they have the willingness to take necessary steps that could guarantee them good jobs in the future, but they feel frustrated and abandoned by the government. Participant 32 commented: "I will not be here today if the government is doing all it should do to enable the citizens stand on their feet. I had a lot of plan for my future, but I did not get the support I needed". This point of lack of support was echoed by participant 21 who said: "I lost my parents at a very young age, and if the government gave me necessary support, I will not be going about living from waste picking."

Also, some of the participants revealed that they are often targeted by hoodlums in their local communities who wait for their return and subsequently rob them of either their money or some of the good items they may have found during waste picking.

Interestingly, many of the participants were hopeful that their situation will improve once they are able to get help. One of them said "maybe one day I go back to school ... may be someone will help me. I want to train as a boilermaker. Another, a female participant added: "maybe if I learn a skill I can be able to find something to help my family better. My children school clothes I cannot even fix when they have to go school".

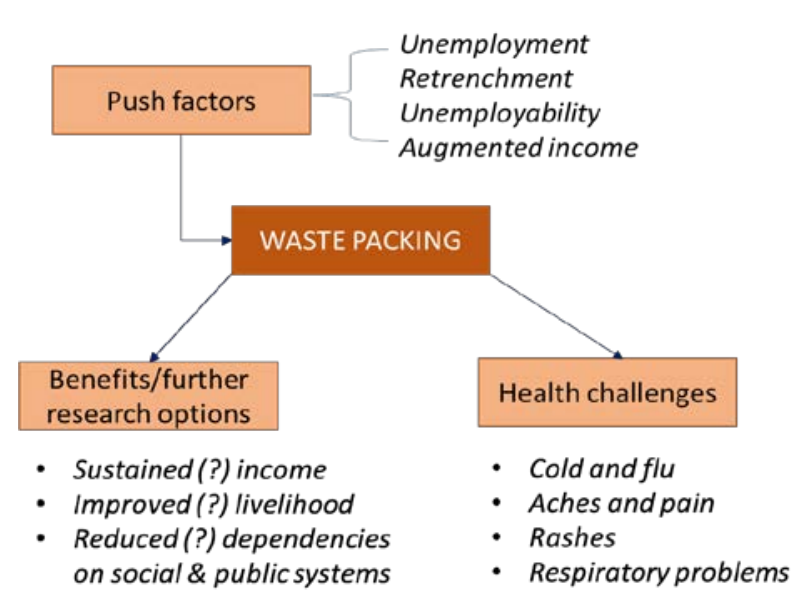

Fig. 2. A summary of the findings

\section{Conclusions}

Necessity, they say, is the mother of invention. With the high level of employment in the South African society, individuals are seeking ways of earning income and taking care of themselves and their families by resorting to waste picking. From interviews with respondents, the participants have been unemployed due to a number of factors: lack of jobs, retrenchment and unemployability. Consequently, they resort to bin scavenging in order to earn a living. Some bin scavengers are however motivated into the job by the need for augmented income.

From a sustainability point, participants are only able to earn incomes that enable them meet their basic needs. For those that have families to take care of meeting those basic needs could even become a huge challenge. Interestingly however, responses from interviewees (three) suggest a potential for bin scavenging to be economically rewarding. In other words, one could earn reasonable income from bin scavenging if one focuses on specific items like furniture and computers that yield more income than other items. To achieve the necessary operational capacity for economically rewarding bin scavenging, financial support, including also support from government is required to enable the scavengers acquire necessary facilitators. If that is done, bin scavenging could sufficiently yield sustainable income, improved livelihoods for the scavengers and their families, and also boost their economic contribution capacity.

Thus, bin scavengers are facing a challenge of lack of financial support that would aid them to achieve sustainable capacity. A further challenge that bin scavengers are facing relates to the health risks associated with bin scavenging. Bin scavengers expose themselves to huge dirt and health hazards 
and as a result suffer from colds and flu, aches and pain, rashes, bent backs, and respiratory problems, and indeed could also cause health problems to members of their families. A further challenge in that regard is that owing to financial handicap, the bin scavengers are not able to afford necessary medication for addressing such health challenges. On their part, the government is seemingly falling behind in their obligation to provide medical support for these scavengers who also face a further challenge of being stigmatised because of the nature of work they do. The implication of these trends is that bin scavengers face the risk of early death due to the accumulated effect of the bin scavenging induced health risks they face. A further implication of the aforementioned health challenges and the stigmatisation and struggle with life is psychological problems in the form of mental illness, increased anxiety, depression and suicide. Finally, they also face the risk of being robbed of their hard-earned money or items from bin scavenging.

\section{Implications of the Study}

In explaining the implications of this study, we take a two-step approach. First, we draw from the emergent cues from this study, analysed in tandem with broad knowledge on unemployment and poverty, to offer policy guidelines for ensuring not only effective waste management but also leveraging the economic contribution potentials. Following that, we suggest directions for future research towards knowledge development in this area and informing practice as well as improving the well-being of waste pickers.

Unemployment, poverty and inequality continue to take centre stage as major challenges in sub-Saharan Africa. Within the South African context, the government has repeatedly taken measures to fight these challenges [89]. Some of the efforts have been geared towards accelerated collaboration with the private sector through enterprise development programmes and extended public works programme $^{1}$ (EPWP). With reference to enterprise

1 The Expanded Public Works Programme (EPWP) is a key South African government initiative, which aims to contribute to coming up with and improving decent work and sustainable livelihoods, education, health, rural development, and food security. EPWP has its origins in Growth and Development Summit (GDS) of 2003. At the Summit, four themes were adopted, one of which was 'More jobs, better jobs, decent work for all'. The GDS agreed that public works programmes 'can provide poverty and income relief through temporary work for the unemployed to carry out socially useful activities'. One of development, the government has introduced a number of legislations that aim to support small businesses. Even with an emerging small business community, it has been noted that their attempts at creating the much needed employment falls short owing to several other challenges such as insufficient start-up capital and proper business management understanding. These have proven to be difficult for the small business to surmount leading to the demise of many small businesses. The outcome of this is a negative employment outlook. If a nation has many unemployed citizens, it is difficult to improve standards of living and create an equal society [90]. With unemployment comes the desperate attempt for survival. Out of desperation, many opt for 'not so glamorous' jobs including waste picking.

More than 20 years after the first democratic elections in 1994, several challenges such as unemployment still remain unsolved. South Africa experiences high levels of unemployment and poverty. The rate of unemployment is $27.6 \%$ (Statistics South Africa, 2019). It ranks third in the world in terms of the highest out of work people between the ages of 15 to 24 [91]. As one of the most unequal societies in the world according to the World Bank (2015), access to quality basic services, such as education, health care, and essential infrastructure in South Africa is marginal and therefore explains why many would rather opt for odd jobs for survival. This current study highlights central issues that connect to the unemployment, poverty and imbalance in the South African setting. In the recent past, there has been an increase in researches on waste picking, a trend which seems to have been inspired by the renewed pledge of the United Nations to improve health and living standards of people as well as look at ways to reduce inequality especially among the developing economies. It is known that the poorest people are found in the developing countries [68] and because of the limited opportunities for human advancement, many seek alternative (often very informal) means to survive. While studies on waste picking are not rare in sub-Saharan Africa e.g. [55], [70], not much effort is invested into explaining the peculiar significance of socioeconomic implications of waste picking. From the purview of waste picking as a livelihood activity, issues of well-being, quality of life, vulnerabilities of waste pickers should

the prescripts of the EPWP is to use labour-intensive methods which allow the drawing of a significant number of participants into the Programme to do the work. Excerpted from http://www.epwp.gov.za/ 
constitute the epicentre of government decisionmaking and social policy debates. This should be seen as part of government's intervention to advance the welfare of its citizens.

In line with that conceptual viewpoint of waste picking as a livelihood activity, this study aimed to contribute to the understanding of the socioeconomic lens of waste picking in South Africa. From the discussion undertaken earlier, unemployment is a major threat to the South African society. Pushed by the challenging circumstances, the individuals are braving up and seeking ways to earn a living. Towards achieving that, they are however exposing themselves to major health hazards that do not only have serious consequences for them and their families but also for the economy that in the long-term suffers loss of human capital, tax revenue, and the potentials for individuals to actively contribute to sustainable economic growth. With time, individuals who stay in the unemployed cycle and are not able to meet their individual needs let alone the needs of their family, and may become a much heavier burden for the society may resort to one form of crime or the other. When this point is reached, the individual does not only become an economic burden but also a danger to the society. There is pertinent need for genuine welfare reform that caters for the needs of individuals in the unemployed cycle. Furthermore, there is need for a genuine hands-on-deck strategy to drive employment generation. Within that job creation drive, there is need for modern approaches to waste management to be embraced towards ensuring proper collection, recycling and reprocessing the items for re-use, after all there is some economic value in these items hence they are being scavenged. A way forward could be to borrow from Western approaches (for example in Germany) in effectively managing waste towards not only ensuring a healthy society but also ensuring healthy and well paid employment in the process.

In their study, [70] recommended integrating waste pickers into the formal waste management system in South Africa. We support that logic and suggest that towards leveraging and optimising the economic input of individuals who waste pick for survival, and in that drive propel sustainable economic growth, a taskforce could be put in place to mobilise waste pickers and recruit them, as well as provide them relevant training tailored in line with healthy and good standard practice. Adequate public health mechanisms must be ensured towards providing necessary medical support to those who regularly need its services, and as this study has shown, the continuous practice of waste picking is synonymous with ill health and pressure on public health systems. To boost the impact of the taskforce tool, technical proficiency from Western countries with relevant waste management experience could be leveraged.

Government support could also take the form of providing waste pickers with the much-needed financial support to enable them acquire necessary operational capacity for achieving the economic capacity to fully meet the needs of themselves and their families and also contribute to economic growth. As results from this study have shown, sustainable and economy impacting waste picking can be achieved, if adequately funded.

Finally, in Western societies, effective waste management machinery is put in place and contributes a fair share to the economy. sub-Saharan African countries can borrow a leaf from that approach towards propelling economy impacting entrepreneurial activity in Africa [93].

\section{Future Research Directions}

Above, practical guides for a hands-on-deck approach for effective waste management have been forwarded. The recommended approach which is sustainable economic growth focus is not only aimed at mitigating the health hazards that waste pickers are exposed to but also towards providing waste pickers with a means of earning a living and becoming active contributors to the economic wheel. Towards a comprehensive strategy for achieving the proposed sustainable economic growth, researchers have a major role to play. More investigation of waste scavenging in South Africa is essential towards illuminating clearly the operational modus, the challenges that waste pickers face, including the associated health hazards. Researchers should invest more effort into highlighting these dynamics and leverage the insights to guide policy makers. In that regard, researchers could also draw from conventional practice from countries with established successful waste management record.

Also, as flagged in this study, however based on limited evidence (three responses), bin scavenging could be a sustainable economic activity with potential for contributing to economic growth, if necessary supportive measures for achieving adequate operational capacity are ensured. Future research could enhance knowledge and inform policy by shedding more light on the sustainable economic potential of waste picking. Bearing in mind that one limitation of this study is that only 
scavenging activities involving household items such as bottles, plastics, furniture, computers, amongst others, were considered, future research should also seek to explore other items and shed light on which particular items offer potentials for sustainable economic activity. Finally, future research should seek to illuminate a range of mechanisms that could be utilised in enhancing sustainable economic capacity of bin scavenging activity.

\section{References:}

[1] Statistics South Africa. 2019. Quarterly Labour Force Survey: Quarter 1 (January to March) $2010 . \quad$ Retrieved from: http://www.statssa.gov.za [Accessed on 27 December 2019].

[2] Peres, T.S., 2016. Stigma management in waste management: An investigation into the interactions of 'waste pickers' on the streets of Cape Town and the consequences for agency (Doctoral dissertation, University of Cape Town).

[3] Samson, M., 2010. Reclaiming livelihoods: the role of reclaimers in municipal waste management

systems. http://www.groundwork.org.za/Public ations/Reclaiming\%20Livelihoods.pdf.

(Accessed on 18 December 2019).

[4] Viljoen, J.M.M., Blaauw, P.F. \& Schenck, C.J., 2012. The role and linkages of buy-back centres in the recycling industry: Pretoria and Bloemfontein (South Africa). Acta Commercii, 12(1), pp.1-12.

[5] Nyathi, S., Olowoyo, J.O. \& Oludare, A., 2018. Perception of Scavengers and Occupational Health Hazards Associated with Scavenging from a Waste Dumpsite in Pretoria, South Africa. Journal of Environmental and Public Health.

[6] Vázquez, J.J., 2016. The stigma of making a living from garbage: Meta-sterotypes of trash-pickers in León (Nicaragua). Scandinavian Journal of Psychology, 57(2), pp.122-128.

[7] Chokhandre, P. \& Kashyap, G.C., 2017. Assessment of Psychological Well-being of Waste-pickers of Mumbai, India. Asian Journal of Epidemiology, 10(3), pp.138-143.

[8] Simatele, D. \& Etambakonga, C.L., 2015. Scavenging for solid waste in Kinshasa: a livelihood strategy for the urban poor in the Democratic Republic of Congo. Habitat International, 49, pp.266-274
[9] Njoroge, K.S., Wokabi, M.S., Ngetich, K. \& Kathuri, N.M., 2013. Influence of informal solid waste management on livelihoods of urban solid waste collectors: a case study of Nakuru Municipality, Kenya. International Journal of Humanities and Social Science, 3(13), pp.95-108.

[10] Mehay, C., 2017. Plastics Recycling Figures More South Africans Recycling. [online] Plasticsnews.co.za. Available at: http://www.plasticsnews.co.za/plasticsnews/pla sticsrecycling-figures-,ore-south-africansrecycling.html [Accessed 21 December 2019].

[11] Benson, K. \& Vanqa-Mgijima, N., 2010. Organizing on the streets: A study of reclaimers in the streets of Cape Town. International Labour Research and Information Group (ILRIG), WIEGO Organizing Series. Available at: $\quad h t t p: / / w w w . \quad$ inclusivecities. org/toolbox/Organizing_on_the_Streets_web. Pdf [Accessed 21 December 2019].

[12] Viljoen, J.M.M., 2014. Economic and social aspects of street waste pickers in South Africa. Unpublished $\mathrm{PhD}$ (Economics), University of Johannesburg. Available at: https://ujdigispace.uj.ac.za/ [accessed December 2019].

[13] Günther, I. \& Launov, A., 2012. Informal employment in developing countries: Opportunity or last resort? Journal of Development Economics, 97(1), pp.88-98.

[14] Quazi, T. \& Dobson, R., 2013. Inclusion of the waste pickers into national and local government plans. [Online] Available: http://aet.org.za/2013/01/inclusion-ofwastepickers-into-national-and-local-governmentplans/. [Accessed December 2019].

[15] Clark, C., Pike, C., McManus, S., Harris, J., Bebbington, P., Brugha, T., Jenkins, R., Meltzer, H., Weich, S. \& Stansfeld, S., 2012. The contribution of work and non-work stressors to common mental disorders in the 2007 Adult Psychiatric Morbidity Survey. Psychological Medicine, 42(4), pp.829-842.

[16] Silva, D.A., Fassa, M.C., Kriebel, A.G., 2006. Minor psychiatric disorders among Brazilian ragpickers: A cross-sectional study. Environmental Health, 5, 1-9.

[17] Pallipparambil, G.R., 2014. The Surat plague and its aftermath. Unpublished essay. Available at:

http://www.montana.edu/historybug/yersiniaess ays/godshen.html 
[18] Schenck, R., Blaauw, D. and Viljoen, K., 2016. Enabling factors for the existence of waste pickers: A systematic review. Social Work, 52(1), pp.35-53.

[19] Yang, B., \& Lester, D., 1994. The social impact of unemployment, Applied Economics Letters, 23, 223-226.

[20] Saunders, P., 2002. The direct and indirect effects of unemployment on poverty and inequality. The Social Policy Research Centre, Discussion Paper No. 118.

[21] Norström, F., Virtanen, P., Hammarström, A., Gustafsson, P.E., \& Janlert, U., 2014. How does unemployment affect self-assessed health? A systematic review focusing on subgroup effects. BMC Public Health, 14:1310. http://www.biomedcentral.com/14712458/14/1310.

[22] Norström, F., Waenerlund, A-K., Lindholm, L., Nygren, R., Sahlen, K-G., \& Brydsten, A., 2019. Does unemployment contribute to poorer health-related quality of life among Swedish adults? BMC Public Health, 19:457. https://doi.org/10.1186/s12889-019-6825-y

[23] Ahn, N., Garcia, J.R., \& Jimeno, J.F., 2004. The impact of unemployment on individual well-being in the EU. European Network of Economic Policy Research Institute Working Paper No. 29.

[24] Nagel, K., 2015. Relationships between unemployment and economic growth - the review (results) of the theoretical and empirical research. Journal of Economics and Management, pp.65-79.

[25] Imran, M., Mughal, K. S., Salman, A., \& Makarevic, N., 2015. Unemployment and Economic Growth of Developing Asian Countries: A Panel Data Analysis. European Journal of Economic Studies, pp.147-160.

[26] Enejoh, S. Y., \& Tsauni, A. M., 2017. An Analytical Study of the Impact of Unemployment on Economic Growth in Nigeria (1970-2016). IOSR Journal of Humanities and Social Science, pp.74-81.

[27] McClelland, A., \& Macdonald, F., 1998. The social consequences of unemployment. Business Council of Australia Discussion Forum.

[28] Jackson, S \& Crooks, M 1993, Existing but not living: a research project canvassing the aspirations and views of long-term unemployed Australians, Brotherhood of St Laurence, Melbourne.

[29] Clark, A.E., and Oswald, A.J., 2002. Wellbeing in panels. Mimeo, DELTA, Paris.
[30] Frey, B.S., and Stutzer, A., 2002. Happiness \& Economics, Princeton University Press, Princeton, NJ.

[31] King, A., 1998. Income poverty since the early 1970s, in R. Fincher and J. Niewenhuysen, (eds.), Australian Poverty: Then and Now, Melbourne University Press, Melbourne, 71102.

[32] Weatherburn, D., 2002. The Impact of unemployment on crime, in P. Saunders, and R. Taylor, (eds.), The Price of Prosperity. The Economic and Social Costs of Unemployment, University of New South Wales Press, Sydney, 226-48.

[33] Gyekye, K.B. \& Kyei, K.A., 2011. Determinants of unemployment in Limpopo province in South Africa: exploratory studies. Journal of Emerging Trends in Economics and Management Sciences, 2(1), pp.54-61.

[34] Hunter, B. and Taylor, J., 2002. An overview of the costs of indigenous unemployment. In The price of prosperity: the economic and social costs of unemployment. UNSW Press.

[35] Brooks, K., Filmer, D.P., Fox, M.L., Goyal, A., Mengistae, T.A., Premand, P., Ringold, D., Sharma, S. \& Zorya, S., 2014. Youth employment in Sub-Saharan Africa: Overview. In Africa development forum.

[36] Bell, D.N. \& Blanchflower, D.G., 2010. UK unemployment in the great recession. National Institute Economic Review, 214(1), pp. R3R25.

[37] Breetzke, G.D., 2018. The concentration of urban crime in space by race: evidence from South Africa. Urban Geography, 39(8), pp.1195-1220.

[38] Sosibo, K., 2015. Xenophobia: What did we learn from 2008? Mail \& Guardian, 24.

[39] Siko, J.A., 2015. " Democratic" Foreign Policy Making and the Thabo Mbeki Presidency: A Critical Study (Doctoral dissertation, University of South Africa).

[40] Chalfin, A. \& McCrary, J., 2017. Criminal deterrence: A review of the literature. Journal of Economic Literature, 55(1), pp.5-48.

[41] Verrinder, N., 2013. Untangling the determinants of crime in South Africa. Master's Thesis. Cape Town: University of Cape Town.

[42] Hilker, L.M. \& Fraser, E., 2009. Youth exclusion, violence, conflict and fragile states. Social Development Direct, 30.

[43] Potter, K., 2016. Working hard: Governmental incentives to combat long-term unemployment. 
Journal of Multistate Taxation and Incentives, 26(5).

[44] Kramarz, F., \& Viarengo, M., 2015. Using education and training to prevent and combat youth unemployment, European Expert Network on Economics of Education (EENEE) Analytical Report 22. Prepared for the European Commission.

[45] OECD, 2013. Tackling long-term unemployment amongst vulnerable groups. Accessed 12.03.2020 at: https://www.oecd.org/cfe/leed/Tackling\%20Lo ng_Term\%20unemployment_\%20WP_covers.p df.

[46] International Labour Organisation (ILO), 2017. Employment policy implementation mechanisms in Germany and the United Kingdom. Employment Research Brief.

[47] Musette, M.S., 2014. Employment policies and active labour market programmes in Algeria. ETF Working Together Learning for life. European Training Foundation.

[48] Zimmerman, K. and Fuertes, V. (2014), Employment policy implementation mechanism in the European Union, the United Kingdom and Germany (Employment Working Paper, No.160, Employment Policy Department, Geneva: ILO).

[49] Mpanju, A.K., 2012. The impact of foreign direct investment on employment creation in Tanzania. International Journal of Business Economics \& Management Research, 2(1), pp.126-139.

[50] Chinyelu, U., 2014. Foreign Direct Investment and Employment Nexus: A Case of Nigeria (1981- 2012). Masters dissertation, Department of Economics, University of Nigeria.

[51] Tshepo, M., 2014. The impact of foreign direct investment on economic growth and employment in South Africa: A time series analysis. Mediterranean Journal of Social Sciences, 5(25), p.18.

[52] Kariuki, C., 2015. The determinants of foreign direct investment in the African Union. Journal of Economics, Business and Management, 3(3), pp.346-351.

[53] Department of Trade \& Industry (2015). [Online] Available at: http://www.thedti.gov.za/. [Accessed on December 2019].

[54] Statistics South Africa. 2017. Quarterly Employments Statistics. [dataset]. Pretoria: Statistics South Africa. Available on http://www.statssa.gov.za/?m=2017. [Accessed on 29 December 2019].
[55] Makhubele, M., Ravhuhali, K., Kuonza, L., Mathee, A., Kgalamono, S., Made, F., Tlotleng, N., Kootbodien, T., Ntlebi, V., Wilson, K., \& Naicker, N., 2019. Common mental health disorder among informal waste pickers in Johannesburg, South Africa 2018: A crosssectional study. International Journal of Environmental Research and Public Health, 16, 2618; doi:10.3390/ijerph16142618

[56] WIEGO. 2011. Informal economy: waste pickers Cambridge: women in informal employment, globalizing and organizing. Available at: http://wiego.org/informaleconomy/occupational-groups/waste-pickers. [accessed on 29 December 2019].

[57] Statistics South Africa 2010. Social profile of South Africa, 2002-2009. [Online] Available http://www.statssa.gov.za/publications/Report03-19-00/Report-03-19-002009.pdf [Accessed December 18, 2019].

[58] Pillay, U., 2010. Indigent exit strategy of the city of Tshwane. Pretoria, Human Sciences Research Council (HSRC).

[59] Mamphitha, D., 2011. The role played by subsistence waste pickers in reclying. Unpublished master's dissertation. Department of Business Administration, University of Pretoria, South Africa

[60] Schenck, C., Blaauw, D. \& Viljoen, K., 2012. Unrecognized waste management experts: challenges and opportunities for small business development and decent job creation in the waste sector in the Free State. ILO.

[61] Gunsilius, E., 2012. Role of the informal sector in solid waste management and enabling conditions for its integration: Experiences from GTZ. German Technical Cooperation Agency (GTZ), Eschborn.

[62] Scheinberg, A. \& Savain, R., 2015. Valuing informal integration: Inclusive recycling in North Africa and the Middle East. German Corporation for International Cooperation (Deutsche Gesellschaft für Internationale Zusammenarbeit.

[63] United Nations, 1997. Glossary of environment statistics. Studies in methods.

[64] Downs, M. \& Medina, M., 2000. A short history of scavenging. Comparative Civilizations Review, 42(42), p.4.

[65] Newcomer, D.J., 2015. Coping with Naples' Toxic Waste Crisis. Can the Campania countryside survive the damage wreaked upon it by decades of illicit trash dumping? http://www.earthisland.org/journal/index.php/ar 
ticles/entry/coping_with_naples_toxic_waste_c risis/.

[66] Hoornweg, D. \& Bhada-Tata, P., 2012. What a waste: a global review of solid waste management (Vol. 15, p. 116). World Bank, Washington, DC.

[67] Afon, A., 2012. A survey of operational characteristics, socioeconomic and health effects of scavenging activity in Lagos, Nigeria. Waste Management \& Research, 30(7), pp.664-671.

[68] United Nations, 2019. Ending poverty. Available online at

https://www.un.org/en/sections/issuesdepth/poverty/. Accessed on 6 April, 2020.

[69] Thirarattanasunthon, P., Siriwong, W., Robson, M. \& Borjan, M., 2012. Health risk reduction behaviors model for scavengers exposed to solid waste in municipal dump sites in Nakhon Ratchasima Province, Thailand. Risk Management and Healthcare Policy, 5, p.97.

[70] Schenck, C., Blaauw, P., Viljoen, J. \& Swart, E. (2019). Exploring the potential health risks faced by waste pickers on landfills in South Africa: A socio-ecological perspective. International Journal of Environmental Research and Public Health, 16, 2059; doi:10.3390/ijerph16112059.

[71] Jan, A., Rehman, A.U., Khan, I.U., \& Khan, M. 2018. Governance problems and effects of health hazards on scavenger children's and their quality of life in Pakistan. Journal of Research and Ecology, 6(1), pp.1741-1749.

[72] Senior, K. \& Mazza, A., 2004. Italian "Triangle of death" linked to waste crisis. The Lancet Oncology, 5(9), pp.525-527.

[73] Triassi, M., Alfano, R., Illario, M., Nardone, A., Caporale, O. \& Montuori, P., 2015. Environmental pollution from illegal waste disposal and health effects: A review on the "Triangle of Death". International Journal of Environmental Research and Public Health, 12(2), pp.1216-1236.

[74] Franceschi, S.; Montella, M.; Polesel, J.; la Vecchia, C.; Crispo, A.; dal Maso, L.; Casarin, P.; Izzo, F.; Tommasi, L.G.; Chemin, I.; et al. 2006. Hepatitis viruses, alcohol, and tobacco in the etiology of hepatocellular carcinoma in Italy. Cancer Epidemiol. Biomark. Prev., 15, 683-689.

[75] Fusco, M.; Girardi, E.; Piselli, P.; Palombino, R.; Polesel, J.; Maione, C.; Scognamiglio, P.; Pisanti, F.A.; Solmone, M.; di Cicco, P.; et al. 2008. Epidemiology of viral hepatitis infections in an area of southern Italy with high incidence rates of liver cancer. Eur. $J$. Cancer, 44, 847-853.

[76] Bowling, A., 2002. An" inverse satisfaction law"? Why don't older patients criticise health services? Journal of Epidemiology and Community Health, 56(7), p.482.

[77] Anderson, K. \& McGrath, L., 2014. Exploring embodied and located experience: Memory Work as a method for drug research. International Journal of Drug Policy, 25(6), pp.1135-1138.

[78] Mattila, O., Toppinen, A., Tervo, M. \& Berghäll, S., 2013. Non-industrial private forestry service markets in a flux: results from a qualitative analysis on Finland. Small-scale Forestry, 12(4), pp.559-578.

[79] Skinner, J., 2012. A Four-part Introduction to the Interview: Introducing the Interview; Society, Sociology and the Interview; Anthropology and the Interview; Anthropology and the Interview-Edited. The Interview: An Ethnographic Approach, pp.1-50.

[80] Leung, L., 2015. Validity, reliability, and generalizability in qualitative research. Journal of Family Medicine and Primary Care, 4(3), pp.324-327.

[81] Connelly, L.M., 2016. Trustworthiness in qualitative research. Medsurg Nursing, 25(6), pp.435-437.

[82] Perez, T.S., 2019. In support of situated ethics: Ways of building trust with stigmatised 'waste pickers' in Cape Town. Qualitative Research, 19(2), pp.148-163

[83] WIEGO, nd. https://www.wiego.org/informaleconomy/occupational-groups/waste-pickers

[84] Strauss, A. and Corbin, J., 1998. Basics of qualitative research techniques. Thousand Oaks, CA: Sage publications.

[85] Thomas, D. R., 2006. A General Inductive Approach for Analyzing Qualitative Evaluation Data, American Journal of Evaluation, 27(2), 237-246.

[86] Opute, A. P. and Madichie, N., 2017. Accounting-Marketing integration, Dimensions and antecedents: Insights from a Frontier Market. Journal of Business and Industrial Marketing, 32(8), 1144-1158.

[87] Bryman, A. and Burgess, R.G., 1994. Reflections on qualitative data analysis, in Bryman, A. and Burgess, R.G. (Eds), Analyzing Qualitative Data, Routledge, London, pp. 216226.

[88] Smith, J. and Osborn, M., 2003. Interpretive phenomenological analysis, in Murray, M. and Chamberlain, K. (Eds), Qualitative Health 
Psychology - Theories and Methods, Sage, London.

[89] Nxopo, Z., 2014. The role of government in empowering female entrepreneurs in the Western Cape, South Africa (Unpublished dissertation, Cape Peninsula University of Technology).

[90] Obama, B. 2018. President Obama's speech for Mandela's centenary, Johannesburg, South Africa.

[91] Global

risk 2014. WEF_GlobalRisks_Reoprts_2014.pdf. Accessed 6 ${ }^{\text {th }}$ March 2020.

[92] World bank 2015. Worldbank.org/en/country/southafrica/overvie w. Accessed 14 $4^{\text {th }}$ December 2019.

[93] Opute, A. P. (2020). Small and Medium Enterprises Marketing: Innovation and Sustainable Economic Growth Perspective, in Entrepreneurship Marketing: Principles and practice of SME Marketing. Routledge Publishers.

\section{Creative Commons Attribution License 4.0} (Attribution 4.0 International, CC BY 4.0)

This article is published under the terms of the Creative Commons Attribution License 4.0

https://creativecommons.org/licenses/by/4.0/deed.en_US 


\section{Appendix}

Table 1. A Sample of Excerpts from Memos written during the Interviews

\begin{tabular}{|c|c|}
\hline Shortened response & Expanded response \\
\hline $\begin{array}{l}\text { Why did you start foraging bins? } \\
\text { - } \quad \text { Lost a job } \\
\text { - } \quad \text { Children to feed } \\
\text { - } \quad \text { Wife left me } \\
\text { - } \quad \text { thought of helping } \\
\text { Looked for a job and a friend } \\
\text { asked me to go work with him } \\
\text { Augment an income - I do this } \\
\text { part time }\end{array}$ & $\begin{array}{l}\text { This [business] started when I lost my job } \\
\text { If I do not do this, I am unable to feed my children. I } \\
\text { don’t have a wife. The wife left me } \\
\text { When my parents lost their job I decided to start doing } \\
\text { something in order to assist because there are brothers, } \\
\text { sisters } \\
\text { When I finished school they did not provide any job. } \\
\text { So a friend of mine who did this said I can work with } \\
\text { him. I must say at least I am able to do something for } \\
\text { myself now } \\
\text { I do this when I can. I have a job but you see the items } \\
\text { sell and so I use the things I pick to make up the small } \\
\text { wage I receive }\end{array}$ \\
\hline $\begin{array}{l}\text { Is the money you make enough for } \\
\text { your needs? } \\
\text { - Not at all } \\
\text { - Certainly not }\end{array}$ & $\begin{array}{l}\text { - Of course not. I have many needs but I'm able to buy } \\
\text { the basics such as bread and sausages } \\
\text { - } \quad \text { Never enough } \\
\text { I keep looking for extra work such as gardening, } \\
\text { washing clothes } \\
\text { - I work in the church on weekends for doggie bags }\end{array}$ \\
\hline $\begin{array}{l}\text { Any other aspirations? } \\
\text { - } \quad \text { Find a paid job } \\
\text { - } \quad \text { Apprenticeship training } \\
\text { - Back to school }\end{array}$ & $\begin{array}{l}\text { - I will continue to search for job, but honestly there are } \\
\text { no jobs. } \\
\text { - I hope I will find apprenticeship training. I want to } \\
\text { train as a boilermaker } \\
\text { - Go back to school. May be someone will help me to } \\
\text { fund my education so that I can get better skills for } \\
\text { paid jobs }\end{array}$ \\
\hline $\begin{array}{l}\text { How do you think you can be } \\
\text { helped? } \\
\text { - Government should create } \\
\text { more jobs } \\
\text { - Financial support to start a } \\
\text { small business } \\
\text { Opportunities for } \\
\text { apprenticeship }\end{array}$ & $\begin{array}{l}\text { - If I can get a good job, I will be happy. This work is } \\
\text { not very good. I get sick and I think it is because of this } \\
\text { work. The government can create more jobs } \\
\text { - The government can provide financial support to help } \\
\text { people like to start small businesses } \\
\text { - Maybe if I learn a skill I can be able to find something } \\
\text { to help my family better. My children school clothes I } \\
\text { cannot even fix when they have to go school }\end{array}$ \\
\hline $\begin{array}{l}\text { Do you get sick often? } \\
\text { - } \quad \text { Cough } \\
\text { - } \quad \text { Headache } \\
\text { Rashes on the fingers/hands }\end{array}$ & $\begin{array}{l}\text { - I have been to the doctor and they said I have certain } \\
\text { germs } \\
\text { - Sometimes, at the government hospitals the queues are } \\
\text { long. So I wait for long and I don't get the medicines } \\
\text { If you see my back and feet, and my stomach, you will } \\
\text { see a lot of rashes. See my hands, it is full of rashes }\end{array}$ \\
\hline $\begin{array}{l}\text { How do you treat the illnesses? } \\
\text { - Not really. I let it go. } \\
\text { - } \quad \text { God helps me }\end{array}$ & $\begin{array}{l}\text { - Sometimes I put some cream to rub over the rashes } \\
\text { - Most times, I sit in my small room and cry to God for } \\
\text { help } \\
\text { - Sometimes, I beg for help on the street to get money to } \\
\text { buy medicine }\end{array}$ \\
\hline
\end{tabular}

